Original Research Paper

\title{
Struktur Komunitas Zooplankton di Perairan Kabupaten Lombok Utara, Provinsi Nusa Tenggara Barat
}

\author{
Muhammad Junaidi $^{1 *}$, Nurliah ${ }^{1}$, Fariq Azhar ${ }^{1}$ \\ ${ }^{1}$ Program Studi Budidaya Perairan Univesitas Mataram
}

\begin{abstract}
Article history
Received: September 22 2018

Revised:November $5^{\text {st }}, 2018$

Accepted: November $16^{\text {st }}, 2018$

Published: November $21^{\text {st }}, 2018$

*Corresponding Author:

Muhammad Junaidi,

Program Studi Budidaya Perairan

Univesitas Mataram, Indonesia

Email:

m.junaidi@unram.ac.id
\end{abstract}

\section{Pendahuluan}

Plankton adalah organisme perairan yang hidup melayang dengan pergerakan pasif dan tidak dapat melawan arus. Plankton terdiri atas fitoplankton dan zooplankton. Fitoplankton bersifat autotrof dan menjadi produsen primer perairan, sedangkan zooplankton merupakan konsumen

\begin{abstract}
Considering that the role of zooplankton in aquatic ecosystems is very important, research is carried out with the aim of analyzing zooplankton community structure which includes the type, abundance, and ecological index, and the relation of zooplankton distribution and water quality in North Lombok Regency Waters.Data collection was designed with a geographical information system (GIS) on 23 observation stations that were determined by simple random techniques.he results of this study indicate that the type and abundance of zooplankton found in the waters of North Lombok Regency are quite varied with the number of genus as many as 9 which are divided into 5 classes. Based on the calculation of the ecological index shows that the zooplankton community structure is in the category of less stable waters. The abundance and ecological index of zooplankton is influenced by the environmental (physical-chemical) conditions of the waters including brightness, $\mathrm{pH}$ and dissolved oxygen.
\end{abstract}

Keywords: zooplankton, community structure, water quality, abundance

Abstrak: Mengingat perananzooplankton dalamekosistem perairan sangat penting, maka dilakukan penelitian dengan tujuan untuk menganalisis struktur komunitas zooplankton yang meliputi jenis, kelimpahan, dan indek ekologi, dan kaitan distribusi zooplankton dankualitasperairan di Perairan Kabupaten Lombok Utara. Pengumpulan data dirancang dengan sistem informasi geografis (SIG) pada 23 stasiun pengamatan yang ditentukan dengan teknik acak sederhana.Hasil penelitian menunjukkan bahwa jenis dan kelimpahan zooplankton yang ditemukan di Perairan Kabupaten Lombok Utara cukup bervariasi dengan jumlah genus sebanyak 9 yang terbagi dari 5 kelas. Berdasarkan perhitungan indeks ekologi menunjukkan bahwa struktur komunitas zooplankton dalam kategori perairan yang kurang stabil. Kelimpahan dan indeks ekologi zooplankton dipengaruhi oleh kondisi lingkungan (fisik-kimia) perairan antara lain kecerahan, $\mathrm{pH}$ dan oksigen terlarut.

Kata kunci : zooplankton, struktur komunitas, kualitas perairan, kelimpahan tingkat pertama yang langsung memangsa fitoplankton. Zooplankton merupakan salah satu biota yang mempunyai peranan penting karena sebagai mata rantai penghubung produser primer dengan biota yang berada pada tingkat trofik yang lebih tinggi (Clark et al., 2001). Zooplankton juga merupakan salah satu komponen dalam rantai makanan yang diukur dalam kaitannya dengan nilai produksi suatu ekosistem. Hal ini dikarenakan 
zooplankton berperan ganda baik sebagai konsumen tingkat pertama maupun konsumen tingkat ke dua, dimana merupakan penghubung diantar plankton dan nekton (Pratono et al., 2005).

Produksi primer fitoplankton dalam suatu perairan dikontrol oleh keberadaan zooplankton pada perairan tersebut (Yuliana dan Ahmad, 2017) dan berbanding lurus dengan keberadaan fitoplankton (Ningrum dan Wijiyono, 2015). Menurut Arinardi (1997) kelimpahan zooplankton sangat tergantung pada kelimpahan fitoplankton, karena fitoplankton adalah makanan bagi zooplankton, dengan demikian kelimpahan zooplankton akan tinggi di perairan yang tinggi kandungan fitoplanktonnya. Selain dipengaruhi ketersediaan makanan (fitoplakton), kelimpahan zooplankton sangat erat kaitannya dengan perubahan lingkungan perairan baik fisik, kimia dan biologis (Wibowo et al., 2004; Aji et al., 2014; Agusta, 2014; Raza'i, 2017). Zooplankton hanya dapat hidup dan berkembang dengan baik pada kondisi perairan yang sesuai. Apabila kondisi lingkungan sesuai, maka zooplankton akan tumbuh dan berkembang dengan baik. Begitu pula sebaliknya, jika kondisi lingkungan dan ketersediaan fitoplankton tidak sesuai dengan kebutuhan zooplankton, maka zooplankton tidak dapat bertahan hidup dan akan mencari kondisi lingkungan yang sesuai.

Kondisi lingkungan yang sesuai bagi zooplankton dapat ditemukan pada perairan yang tidak mendapat tekanan ekologis dari daratan ataupundari perairan itusendiri. Kondisi perairan seperti itu sangat dipengaruhi oleh berbagai aktivitas yang dilakukan oleh masyarakat, baik kegiatan yang dilakukan di daratan maupun kegiatan padaperairan bersangkutan. Demikian halnya keberadaan zooplankton sangat dipengaruhi oleh berbagai kegiatan yang dilakukan oleh masyarakat yang bermukim disekitar perairan Kabupaten Lombok Utara.

Kabupaten Lombok Utara merupakan Kabupaten pesisir yang memiliki potensi sumberdaya pesisir dan laut yang cukup besar. Terdapat tiga pulau kecil (gili) yang disingkat Gili Matra (Meno, Trawangan dan Air). Keindahan ekosistem terumbu karang, keanekaragaman jenis ikan, dan keindahan pantai di Gili Matra, sehingga merupakan destinasi wisata bahari yang terkenal sampai ke mancanegara. Selain dimanfaatkan sebagai kawasan wisata bahari, potensi sumberdaya pesisir dan laut Kabupaten Lombok Utara sebagian lainnya dimanfaatkan sebagai kawasan perikanan budidaya laut dan perikanan tangkap. Kegiatan budidaya laut yang sangat berkembang di Kabupaten Utara adalah budidaya kerang mutiara yang menghasilkan biji mutiara kualitas ekspor yang dikenal dengan julukan south sea pearl dari kerang Pinctada maxima (Wardana et al., 2013).

Dalam rangka pemanfaatan dan pengelolaan sumberdaya pesisir dan laut secara berkelanjutan, terutama dalammenunjang kegiatan ekonomi dan kesinambungan ekosistemnya, maka perairan ini harus dijaga supaya tetap menunjang diversitas organisme dan menghasilkan nilai tambah dari segi estetika dan ketersediaan ikan. Keberadaan ikan dan kesuburan perairan merupakan salah satu indikator adanya zooplankton, mengingat peranan zooplankton dalam ekosistem sebagai konsumer pertama yang memakan fitoplankton, kemudian zooplankton dimakan oleh anak-anak ikan. Berdasarkan fungsi zooplankton dalam perairan tersebut, maka sangat penting untuk melakukan penelitian dengan tujuan untuk menganalisis struktur komunitas zooplankton yang meliputi jenis, kelimpahan, dan indek ekologi, dan kaitan distribusi zooplankton dan kualitas perairan di Perairan Kabupaten Lombok Utara.

\section{Bahan dan Metode}

\section{Lokasi Penelitian}

PenelitianinidilaksanakanpadabulanMei2018

di Perairan Kabupaten Lombok Utara, Provinsi Nusa Tenggara Barat (Gambar 1). Lokasi penelitian terbentangpadaposisi $116^{\circ} 6^{\prime} 38^{\prime \prime}-116^{\circ} 14^{\prime} 33^{\prime \prime}$ BujurTimur dan $8^{\circ} \quad 14^{\prime} \quad 42^{\prime \prime}-8^{\circ} \quad 22^{\prime} \quad 2^{\prime \prime}$ LintangSelatan,yangmencakup empat kecamatan dari selatan ke utara yaitu Kecamatan Pemenang, Tanjung, Gangga, dan Kayangan Kabupaten Lombok Utara.

\section{Pengumpulan Data}

Data utama yang dikumpulkan dalam penelitian ini adalah parameter biologi (zooplankton), sedangkan data penunjang adalah parameter fisik dan kimia perairan. Pengumpulan data dirancang dengan sistem informasi geografis (SIG). Stasiun pengamatan ditentukan dengan teknik acak sederhana (simplerandomsampling) 
(Clarkand Hosking,1986; Morain, 1999). Sebanyak 23 stasiun pengamatan disebar secara proposional pada lokasi penelitian, sehingga dapat mewakili karakteristik wilayah yang survei (Gambar 1). Setiap stasiun pengamatan dan pengambilan contoh ditentukan posisi koordinatnya dengan alat GPS (Global Positioning System).

Sampel zooplankton diambil dengan cara menyaring air lapisan permukaan sebanyak 100 liter dengan menggunakan ember volume 10 liter. Sampel tersebut saring menggunakan plankton net dengan ukuran $45 \mathrm{~mm}$, air sampel yang tersaring dimasukan dalam botol sampel volume $100 \mathrm{ml}$ dan diawetkan dengan menggunakan pengawet lugol sebanyak 2 tetes. Saat analisis, diambil sebanyak 1 $\mathrm{ml}$ menggunakan pipet dan diamati dengan menggunakan Sedgewick Rafter Cell (SRC) dan mikroskop. Masing-masing sampel dilakukan pengulangan pengamatan sebanyak 3 kali. Identifikasi fitoplankton dilakukan sampai tingkat genus dengan bantuan buku Yamaji (1996), dan Nontji (2008).

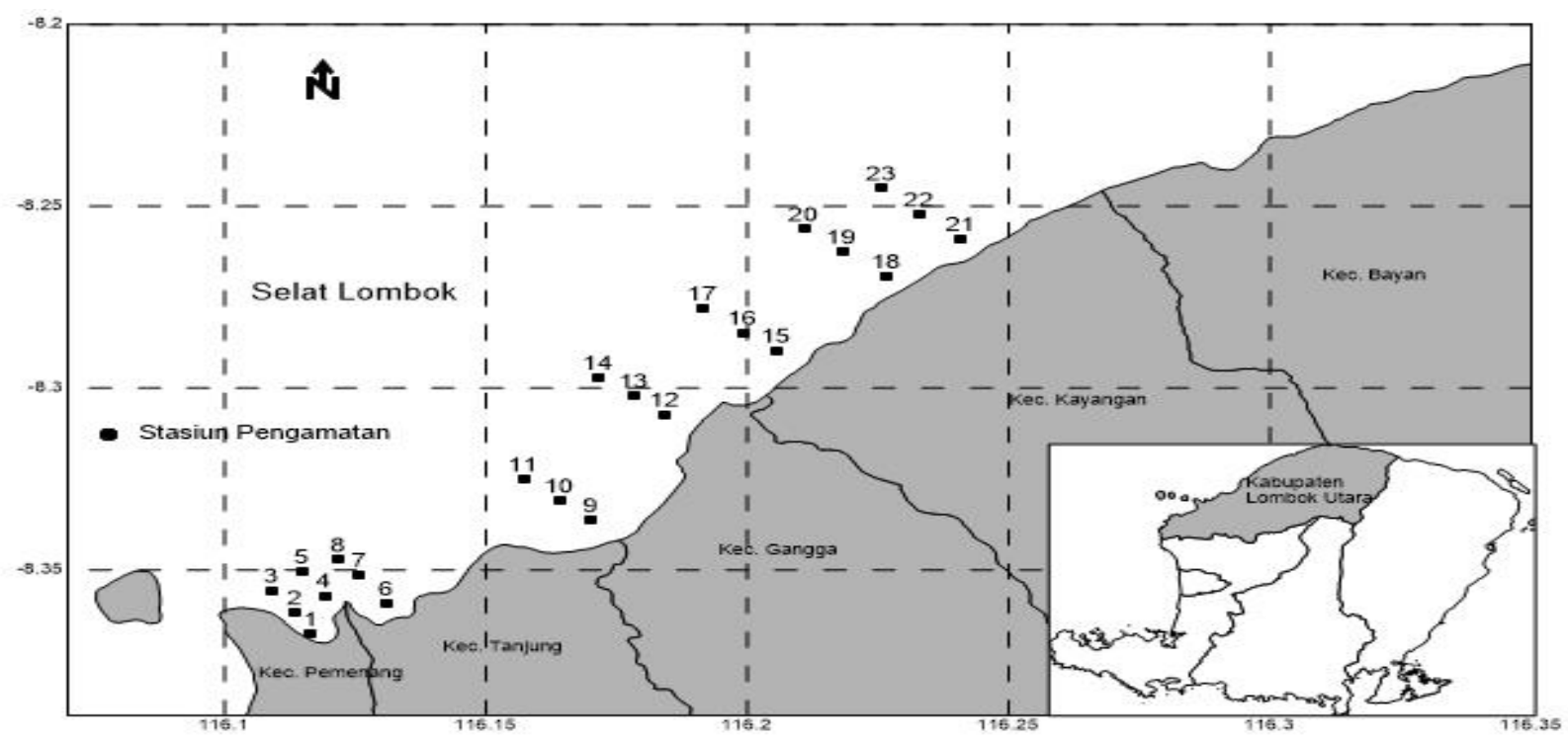

Gambar 1. Lokasi penelitian di Kabupaten Lombok Utara dan stasiun pengamatan zooplankton

Pengukuran parameter perairan yang meliputi suhu, salinitas, $\mathrm{pH}$, kecerahan dan oksigen terlarut dilakukan langsung di lapangan. Selain pengukuran langsung dilapangan, contoh air juga diambil untuk dianalisis parameter fisik dan kimia perairan (kekeruhan, nitrat dan fosfat). Parameter biologi (zooplankton), fisik dan kimia dianalisis di Laboratorium Bioekologi Program Studi Budiaya Perairan Universitas Mataram.

\section{Analisis Data}

Perhitungan kelimpahan zooplankton dilakukan berdasarkan modifikasi APHA (2005) dengan rumus sebagai berikut:

dimana:

$$
N=\frac{O_{i}}{O_{p}} \times \frac{V_{r}}{V_{o}} \times \frac{1}{V_{s}} \times \frac{n}{p}
$$

$\mathrm{N}=$ jumlah individu per liter

$\mathrm{Oi}=$ luas gelas penutup preparat $\left(\mathrm{mm}^{2}\right)$
$\mathrm{O}_{\mathrm{p}}=$ luas satu lapangan pandang $\left(\mathrm{mm}^{2}\right)$

$\mathrm{V}_{\mathrm{r}}=$ volume air tersaring $(\mathrm{ml})$

$\mathrm{V}_{\mathrm{o}}=$ volume air yang diamati $(\mathrm{ml})$

$\mathrm{V}_{\mathrm{s}}=$ volume air yang disaring (1)

$\mathrm{n}=$ jumlah zooplankton pada seluruh lapangan pandang

$\mathrm{p}=$ jumlah lapangan pandang yang teramati

Selain kelimpahan zooplankton, perhitungan beberapa indek ekologi juga dilakukan. Perhitungan indek ekologi tersebut meliputi indek keanekaragaman (Shannon-Wiener Index, H'), indek keseragaman (Evenness Index, E) dan indek dominasi (Simpson's Index, D). Perhitungan indeks tersebut mengacu pada Odum (1971), dengan rumus sebagai berikut:

$$
H^{\prime \prime}=-\sum_{i}^{s} P_{i} \ln \left(P_{i}\right)
$$




$$
\begin{gathered}
E=\frac{H}{\ln (S)} \\
D=\sum_{i}^{S}\left(P_{i}^{2}\right)
\end{gathered}
$$

dimana :

$\mathrm{P}_{\mathrm{i}}=\mathrm{N}_{\mathrm{i}} / \mathrm{N}$

$\mathrm{N}_{\mathrm{i}}=$ jumlahindividugenuske- $\mathrm{i}$

$\mathrm{N}=$ jumlahtotalindividuseluruhgenera

$\mathrm{S}=$ jumlahspesies

Analisis spasial dengan metode kriging (Siregar dan Selamat, 2009), yang terdapat dalam perangkat lunak Surfer 9 (Golden Software, Inc) dilakukan dengan tujuan untuk melihat distribusi spasial zooplankton yang meliputi kelimpahan dan indek ekologi. Metode kriging adalah interpolator geostatistik yang paling sering digunakan dalam analisis spasial yang dapat menghubungkan titiktitik bernilai ekstrim tanpa mengisolasinya sehingga lebih akurat daripada metode regresi (Siregar dan Selamat, 2009; Hadi, 2013). Keunggulan Kriging dibandingkan teknik konturisasi lainnya adalah kemampuannya untuk mengkuantifikasi variansi dari nilai yang diestimasi sehingga tingkat presisi dari hasil estimasi dapat diketahui. Sedangkan analisis statistik korelasi Pearson dilakukan untuk melihat hubungan antara parameter lingkungan (fisik dan kimia) dengan zooplankton. Analisa statistik dilakukan dengan menggunakan perangkat SPSS v 16.

\section{Hasil dan Pembahasan}

\section{Komposisi Jenis dan Kelimpahan}

Berdasarkan hasil identifikasi dan pencacahan zooplankton ditemukan pada lokasi penelitian sebanyak 9 genus, terdiri dari 8 ordo Holostichida (1 genus), Sessilia (1 genus), Cyclopoida (2 genus), Choreotrichida (1 genus), Myodocopida (1 genus), Cirripedia (1 genus), Harpacticoida (1 genus) dan Cladocera (1 genus). Untuk kelas Crustacea ditemukan 6 genus yaitu Balanus, Nauplius, Cylops, Cypridina, Canthocamptus, dan Daphnia. Filum Protozoa 1 genus yaitu Holosticha, Cliaphora 1 genus yaitu favella, dan Antropoda 1 genus yaitu Sacculina. Kelimpahan zooplankton yang ditemukan cukup bervariasi, dimana terdapat satu genus dominan yang ditemukan di lokasi penelitian adalah
Holosticha dengan kelimpahan sebasar 130 ind/l (Tabel 1) dan kelimpahan relatif 44,8\% (Gambar 2).

Genusyang paling sering ditemukan pada lokasi penelitian adalah genus dari kelas Crustacea. Secara keseluruhan zooplankton dilaut didominasi oleh jenis-jenis Crustacea, baik dalam jumlah individu maupun jumlah jenisnya (Odum, 1971) dandominasi Crustacea pada perairan berkaitan dengan sifat omnivora atau pemakan segala (fitoplankton, zooplankton, detritus), sehingga mudah untuk mendapat makanan (Arinardi et al., 1997). Sedangkan menurut Pranoto et al. (2005), kelas crustacea komposisinya lebih tinggi karena umumnya bersifat euryhalin atau lebih mampu bertahan dengan perubahan salinitas yang luas atau beruaya lebih jauh ke muara sungai. Kemudian menurut Mulyadi dan Radjab (2015) menyatakan bahwa adanya dinamika atau variasi komposisi zooplankton secara umum dipengaruhi oleh ketersediaan makanan, kondisi lingkungan yang sesuai, faktor persaingan dan pemangsaan serta pengaruh migrasi vertikal zooplankton.

Distribusi spasial kelimpahan zooplankton disajikan pada Gambar 3a. Zooplankton dengan kelimpahan yang tinggi ditemukan di lokasi dekat dengan muara sungai dan hutan mangrove, karena kawasan tersebut mempunyai unsur hara yang cukup yang berasal dari daratan yang dialirkan dari sungai menuju ke laut. Kondisi yang berbeda diperoleh di Perairan Digul Laut Arafura Papua (Wibowo et al., 2004), dimana zooplankton dengan kepadatan rendah terlihat pada daerah dekat muara sungai dengan kepadatan fitoplankton semakin naik, karena tercukupinya nutrisi. Zooplankton yang mempunyai mobilitas tinggi cenderung bermigrasi daerah yang banyak fitoplanktonnya, agar mendapat ruang untuk bergerak bebas. Kelimpahan zooplankton dipengaruhi oleh kelimpahan fitoplankton yang merupakan akibatdari tingginya kandungan unsur hara terutama nitrat dan fospat yang didukung oleh kondisi lingkungan perairan (Arinardietal, 1997; Patmawati et al., 2018).

\section{Keanekaragaman, Keseragaman dan Dominasi}

Untuk melihat tingkat stabilitas lingkungan perairan, beberapa indeks ekologi zooplankton telah dihitung meliputi indek keanekaragaman (Shannon-Wiener Index, H'), indeks keseragaman 
(Evenness Index, E) dan indeks dominasi (Simpson's Index, D) (Tabel 2). Indeks keanekaragaman menggambarkan kekayaan jenis plankton yang terdapat di suatu perairan. Indeks keseragaman menggambarkan tingkat keseimbangan komposisi jenis, dan indeks dominasi merupakan gambaran ada atau tidaknya suatu jenis atau kelompok plankton yang mendominasi (Odum, 1971). Semakin tinggi nilai keragaman suatu daerah perairan maka perairan tersebut memiliki keragaman yang stabil.

Indek keanekaragaman di lokasi penelitian berkisar antara $0,00-1,03$ dengan nilai rata-rata 0,24. Berdasarkan Odum (1971) nilai ini termasuk dalam kategori keanekaragaman yang rendah dan mempunyai kestabilan komunitas yang rendah. Sebaran spasial indek keanekaragaman ditampilkan pada Gambar 3b. Indeks keanekaragaman pada lokasi yang relatif sangat rendah $(<1)$ tersebar pada seluruh stasiun pengamatan. Indeks keseragaman menunjukkan nilai yang cukup tinggi dengan dengan rata-rata 0,28 . Nilai rata-rata tersebut termasuk dalam kategori kesegaraman rendah (Odum, 1971). Sebaran spasial indek keseragaman ditampilkan pada Gambar 3c. Indeks dominasi zooplankton di lokasi penelitian berkisar antara $0,00-1,03$ dengan nilai rata-rata 0,50 . Nilai indeks dominasi yang mendekati satu menunjukkan adanya jenis yang dominan (Odum, 1971). Indek dominasi yang cukup besar $(>0,5)$ ditemukan pada stasiun 1,2,3,5,8,13,18 dan 21 (Gambar 3d). Dengan demikian, berdasarkan indeks ekologi diperoleh indeks keaneragaman rendah, keseragaman tinggi dan indeks dominasi tinggi, artinya struktur komunitas zooplankton di Perairan Lombok Utara apabila ada faktor lingkungan yang berkurang atau meningkat, maka struktur komunitasnya akan cepat berubah, namun ada kecenderungan terjadi dominansi oleh jenis-jenis tertentu.

Tabel 1. Kelimpahan zooplankton di Perairan Kabupaten Lombok Utara

\begin{tabular}{lllll}
\hline Kelas & Ordo & Genus & $\begin{array}{l}\text { Kelimpahan } \\
\text { (ind/l) }\end{array}$ & $\begin{array}{l}\text { Kelimpahan Relatif } \\
(\%)\end{array}$ \\
\hline Protozoa & Holostichida & Holosticha & 130 & 44,8 \\
Crustacea & Sessilia & Balanus & 30 & 10,3 \\
& Cyclopoida & Nauplius & 33 & 11,5 \\
& & Cyclops & 10 & 3,4 \\
& Myodocopida & Cypridina & 30 & 10,3 \\
& Harpacticoida & Canthocamptus & 13 & 4,6 \\
Cliaphora & Choreotrichida & Favella & 20 & 6,9 \\
Antropod & Cirripedia & Sacculina & 10 & 3,4 \\
\hline
\end{tabular}




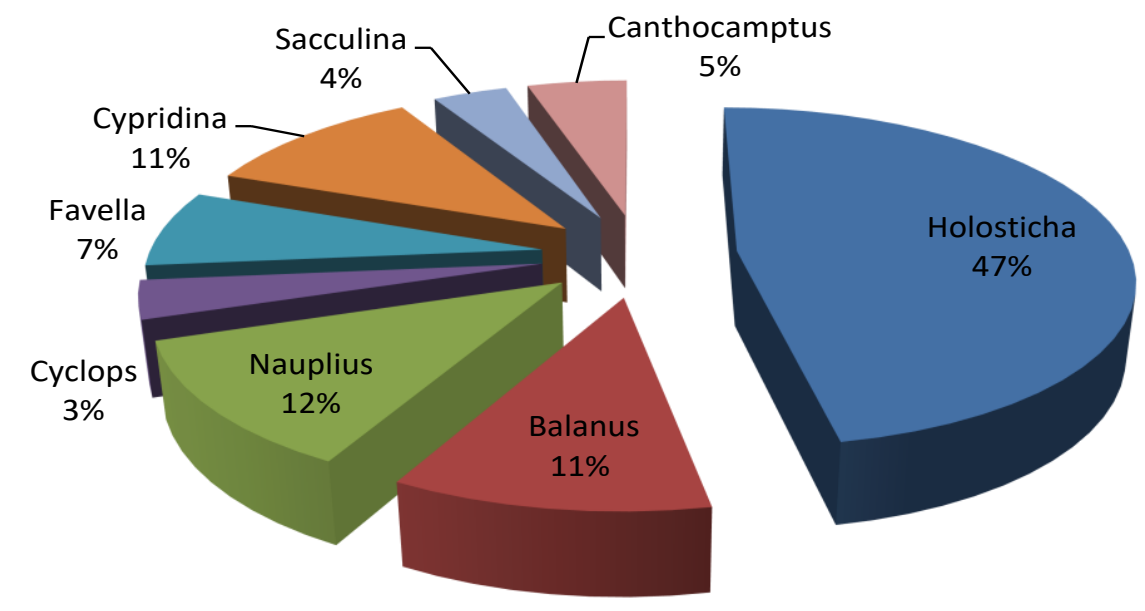

Gambar 2. Kelimpahan relatif zooplankton di Perairan Kabupaten Lombok Utara

Tabel 2. Kelimpahan dan indek ekologi zooplankton di Selat Lombok Kabupaten Lombok Utara

\begin{tabular}{lll}
\hline Peubah & Rata-rata & Kisaran \\
\hline Kelimpahan (ind/l) & 12,6 & $0,0-67,7$ \\
Indeks Keanekaragaman (Shannon-Wiener Index, H) & 0,24 & $0,00-1,03$ \\
Indeks Keseragaman (Evenness Index, E) & 0,28 & $0,00-0,98$ \\
Indek Dominasi (Simpson's Index, D) & 0,50 & $0,00-1,00$ \\
\hline
\end{tabular}



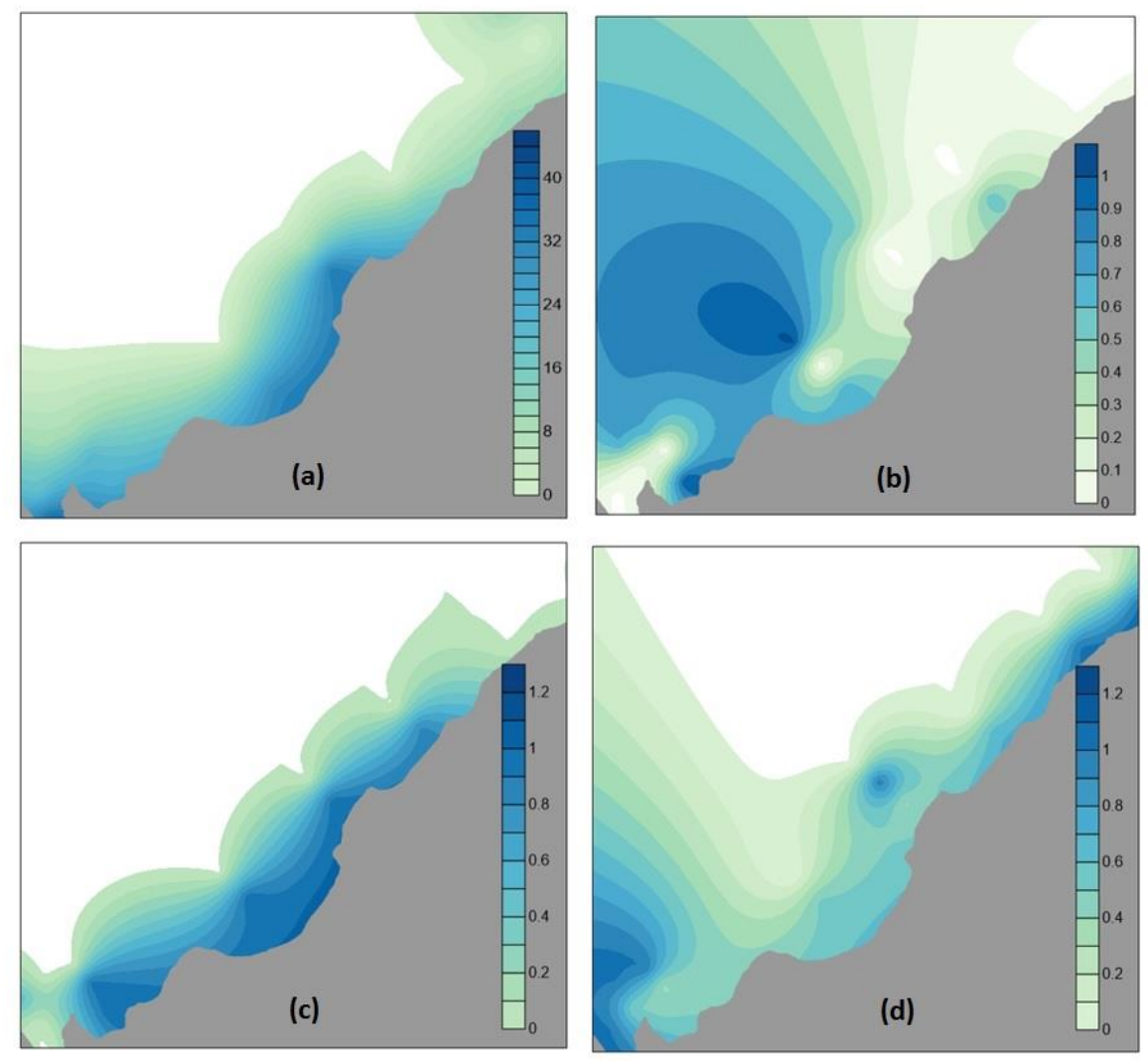

Gambar 3. Distribusi spasial zooplankton di Perairan Kabupaten Lombok Utara

(a) kelimpahan zooplankton (ind/l), (b) indeks keanekaragaman

(c) indeks keseragaman, (d) indeks dominasi

\section{Kondisi Kualitas Perairan}

Hasil pengamatan kondisi kualitas perairan di lokasi penelitian ditampilkan pada Tabel 3 . Parameter kualitas perairan umumnya masih dalam kondisi yang baik untuk mendukung biota laut sesuai baku mutu (MNLH, 2014), kecuali kadar nitrat dan fosfat. Hasil pengamatan suhumenunjukkankisaran30,7 - 31,7 ${ }^{\circ}$ Cdengannilai rata-rata $31,06^{\circ} \mathrm{C}$, kondisi suhu ini masih tergolong dalam kategori baik untuk biotalaut. Menurut Tambaru et al. (2014) kisaran suhu bagi perkembangan zooplankton adalah $28^{\circ} \mathrm{C}-32^{\circ} \mathrm{C}$. Kecerahan perairan di lokasi penelitian menunjukkan nilai yang sangat mendukung pertumbuhan biota laut sesuai baku mutu (MNLH, 2004) dengan nilai rata-rata $14,3 \mathrm{~m}$ (Tabel 3). Tingkat penetrasi cahaya sangat dipengaruhi oleh partikel yang tersuspensi dan terlarut dalam air sehingga mengurangi laju fotosintesis. Tingkat kecerahan yang terukur sangat relatif terhadap kedalaman perairan. Sedangkan kekeruhan dapat menyebabkan efek negatif pada kualitas air, terutama kadar DO, BOD, suhu dan berdampak terhadap keragaman jenis ikan, akibat penurunan fotosintesis, populasi plankton, alga serta mikrofita (Makmur et al., 2012). Hasil pengukuran kekeruhan menunjukkan kisaran 0,13-0,45 NTUdengan nilai rata-rata 0,3 NTU (Tabel 3). Kisaran ini masih memenuhi nilai ambang batas baku mutu peruntukan biota laut yaitu 5 NTU (MNLH, 2004).

Kondisi derajat keasaman $(\mathrm{pH})$ hasil pengukuran lapangan memberikan gambaran bahwa kondisi $\mathrm{pH}$ di lokasi penelitian merupakan perairan yang cenderung basa dengan kisaran $\mathrm{pH}$ antara $8,0-8,2$, hal ini menunjukkan bahwa perairan tersebut cukup ideal untuk pertumbuhan zooplankton. Hasil pengukuran salinitas menunjukkan kisaran29 - 32 ppt dengan nilai ratarata 30,5 ppt (Tabel 3). Oksigen terlarut tercatat dengan kisaran cukup tinggi yaitu kisaran 6,8 - 8,7 $\mathrm{mg} / \mathrm{l}$ dan nilai rata-rata $7,46 \mathrm{mg} / \mathrm{l}$. Nilai oksigen tersebut masih dikategorikan sesuai untuk 
perkembangan biotalaut (MNKLH,2004). Kondisi oksigen terlarut di perairan dipengaruhi antara lain oleh suhu, salinitas, pergerakan massa air, tekanan atmosfir, kelimpahan fitoplankton dan tingkat saturasi oksigen sekelilingnya serta adanya pengadukan massa air oleh angin (Simanjuntak, 2009). Nitrat dan fosfat merupakan unsur hara yang memiliki peran sangat terhadap pembentukan sel jaringan jasad hidup organisme laut dan juga proses fotosintesi oleh fitoplankton (Paiki dan Kalor, 2017).Rata-rata kadar nitrat dan fosfat yang ditemukan di lokasi penelitian berturut-turut adalah 0,158 mg/l, dan 0,033 mg/l (Tabel 3).

Tabel 3 Kondisi fisik dan kimia perairan di Kabupaten Lombok Utara

\begin{tabular}{llllll}
\hline Peubah & Satuan & Kisaran & Rata-rata & Standar deviasi & $\begin{array}{l}\text { Baku } \\
\text { mutu }\end{array}$ \\
\hline Suhu air & ${ }^{\circ} \mathrm{C}$ & $30,7-31,7$ & 31,06 & 0,27 & alami \\
Kecerahan & $\mathrm{m}$ & $4,0-22,0$ & 14,3 & 5,3 & $>3$ \\
Kekeruhan & $\mathrm{NTU}$ & $0,13-0,45$ & 0,3 & 0,07 & $<5$ \\
$\mathrm{pH}$ & & $8,0-8,2$ & 8,09 & 0,07 & $7-8,5$ \\
Salinitas & $\mathrm{ppt}$ & $29-32$ & 30,5 & 0,8 & alami \\
Oksigen terlarut & $\mathrm{mg} / \mathrm{l}$ & $6,8-8,7$ & 7,46 & 0,41 & $>5$ \\
Nitrat $\left(\mathrm{NO}_{3}-\mathrm{N}\right)$ & $\mathrm{mg} / \mathrm{l}$ & $0,152-0,165$ & 0,158 & 0,0034 & 0,008 \\
Fosfat $\left(\mathrm{PO}_{4}-\mathrm{P}\right)$ & $\mathrm{mg} / \mathrm{l}$ & $0,026-0,042$ & 0,033 & 0,0041 & 0,015 \\
\hline
\end{tabular}

*) Baku mutu berdasarkan KEPMENLH No. 51 tahun 2004

\section{Hubungan Zooplankton dengan Kualitas Perairan}

Hubungan antara zooplankton dan kondisi lingkungan perairan telah banyak dibahas dengan menggunakan berbagai analisis (Faiqoh et al., 2015; Hirdan et al., 2016; Widyarini et al., 2017). Untuk melihat hubungan tersebut, dalam penelitian ini hubungan antara zooplankton dengan parameter lingkungan perairan dianalisis dengan menggunakan korelasi Pearson.

Hasil perhitungan korelasi menunjukkan terdapat korelasi secara signifikan antara parameter lingkungan dengan zooplankton baik pada level 99\% $(0,01)$ atau 95\% $(0,05)$ (Tabel 4). Kelimpahan zooplankton di lokasi penelitian berkorelasi sangat signifikan (99\%) terhadap indeks keanekaragaman $(0,604)$ dan berkorelasi signifikan $(95 \%)$ terhadap indeks dominasi $(0,519)$, serta berkorelasi negatif signifikan terhadap kecerahan $(-0,441)$, sedangkan terhadap parameter $\mathrm{pH}$, salinitas, oksigen terlarut, suhu, kekeruhan, nitrat dan fosfat tidak menunjukkan korelasi. Kondisi yang berbeda diperoleh di Kepulauan Seribu (Faiqoh et al., 2015) dan di Muara Sungai Majakerta Indramayu (Widyarini et al., 2017), dimana dengan menggunakan analisis komponen utama diperoleh bahwa kelimpahan zooplankton dipengaruhi oleh kualitas perairan terutama parameter fosfat dan nitrit (Faiqoh et al., 2015), pH dan salinitas (Widyarini et al., 2017). Tingkat korelasi antara kelimpahan zooplankton dengan parameter suhu tergolong kuat, dengan salinitas tergolong kategori sedang, dan dengan $\mathrm{pH}$ dan oksigen terlarut tergolong rendah (Hirdan et al., 2016).

Indeks keanekaragaman menunjukkan korelasi negatif signifikan dengan $\mathrm{pH}$ perairan ($0,652)$, sedangkan dengan parameter lain tidak menunjukkan korelasi. Keanekaragaman ditentukan oleh beberapa faktor atau proses yang terjadi dalam ekosistem, termasuk faktor abiotik seperti nutrien (Spatharis et al., 2007) dan faktor biotik seperti pemangsaan atau kompetisi (Gao dan Song, 2005). Indeks keseragaman menunjukkan korelasi negatif signifikan dengan oksigen terlarut (-0,549), sedangkan dengan parameter lain tidak menunjukkan korelasi. Indeks dominasi berkorelasi negatif signifikan dengan kecerahan (0,490), sedangkan parameter lain tidak menunjukkan korelasi (Tabel 4). 
Tabel 4. Korelasi Pearson antara zooplankton dan parameter kualitas perairan di Kabupaten Lombok Utara

\begin{tabular}{lllll}
\hline Peubah & $\begin{array}{l}\text { Kelimpahan } \\
\text { zooplankton }\end{array}$ & $\begin{array}{l}\text { Indeks } \\
\text { keanekaragaman } \\
\text { Shannon-Wiener } \\
\text { index) }\end{array}$ & $\begin{array}{l}\text { Indeks } \\
\text { keseragaman } \\
\text { (Evenness index) }\end{array}$ & $\begin{array}{l}\text { Indeks dominasi } \\
\text { (Simpson's } \\
\text { index) }\end{array}$ \\
\hline $\begin{array}{l}\text { Indeks keanekaragaman (Shannon- } \\
\text { Wiener index) }\end{array}$ & 0,005 & 1 & 0,219 & 0,049 \\
$\begin{array}{l}\text { Indeks keseragaman (Evenness } \\
\text { index) }\end{array}$ & $0,604^{* *}$ & 0,219 & 1 & 0,059 \\
Indeks dominasi & & & \\
(Simpson's index) & $0,519^{*}$ & 0,049 & 0,059 & 1 \\
pH & $-0,108$ & $-0,652^{* *}$ & $-0,223$ & $-0,143$ \\
Salinitas & 0,293 & 0,211 & 0,339 & 0,053 \\
Kecerahan & $-0,441^{*}$ & $-0,124$ & $-0,101$ & $-0,490^{*}$ \\
Oksigen terlarut & 0,029 & $-0,373$ & $-0,549^{* *}$ & $-0,031$ \\
Suhu & 0,039 & 0,069 & $-0,347$ & $-0,123$ \\
Kekeruhan & 0,081 & $-0,293$ & $-0,067$ & $-0,058$ \\
Nitrat $\left(\mathrm{NO}_{3}-\mathrm{N}\right)$ & $-0,014$ & $-0,107$ & $-0,143$ & 0,184 \\
Fosfat $\left(\mathrm{PO}_{4}-\mathrm{P}\right)$ & 0,357 & 0,137 & 0,357 & 0,191 \\
\hline
\end{tabular}

** Signifikan pada level 99\% (0,01); * Signifikan pada level 95\% (0,05)

\section{Kesimpulan}

Hasil penelitian ini menunjukkan bahwa jenis dan kelimpahan zooplankton yang ditemukan di Perairan Kabupaten Lombok Utara cukup bervariasi dengan jumlah genus sebanyak 9 yang terbagi dari 5 kelas, dimana kelas Crustacea ditemukan 6 genus. Berdasarkan perhitungan indek ekologi yang meliputi, indeks keanekaragaman, indeks keseragaman dan indek dominasi menunjukkan bahwa struktur komunitas zooplankton dalam kategori perairan yang kurang stabil. Kelimpahan dan indeks ekologi zooplankton dipengaruhi oleh kondisi lingkungan (fisik-kimia) perairan antara lain kecerahan, $\mathrm{pH}$ dan oksigen terlarut.

\section{Ucapan Terima Kasih}

Kami ucapkan terima kasih kepada Pihak Kemenristik-Dikti dan LPPM Universitas Mataram atas bantuan dana untuk menyelesaikan penelitian ini. Ucapan terima kasih juga disampaikan kepada saudara Abdul Saddam Mujib, S.Kel, M.Si., Nurul Hidayati, S.Pi., Kadek Puji, S.Pi. atas bantuan dalam pengumpulan data di lapangan sehingga penelitian ini dapat terlaksana dengan baik.

\section{Daftar Pustaka}

Aji, W.P., Subiyanto dan M.R. Muskananfola. 2014. Abundance of Crustacean Zooplankton based on Moon Phases in the Jepara Coastal Waters, Jepara Regency. Diponegoro Journal of Maquares, 3 (3) : 188-196.

American Public Health Association (APHA). (2005). Standart Methods for American Public Health Association. Washington, DC.: American Public Health Association.

Arinardi, O. H., A. B. Sutomo, S.A. Yusuf, E.A. Trimaningsih dan S.H. Riyono. 1997. Kisaran kelimpahan dan komposisi plankton predominan di Perairan Kawasan Timur Indonesia. Jakarta: P3O-LIPI.

Augusta, T.S dan S.U. Evi . 2014. Analysis of Relationship between Water Quality and The Community of Zooplankton and Fish in Hanjalutung Lake . Jurnal Ilmu Hewani Tropika, 3 (2) : 30-35.

Clark, D.R., K.V. Aazem, and G.C. Hays. 2001. Zooplankton abundance and community structure over a $4000 \mathrm{~km}$ transect in the northeast Atlantic. J. of Plankton Research, 23 (4) : 365-37.

Clark,W.A.V.andP.L.Hosking.1986.StatisticalMethods forGeographers.JohnWiley\&Sons,Inc,513pp.

Faiqoh, E., I.P. Ayu, B.Subhan, Y.F. Syamsuni, A.W. Anggoro dan A. Sembiring. 2015. Variasi 
Geografik Kelimpahan Zooplankton di Perairan Terganggu, Kepulauan Seribu, Indonesia . J. Mar. Aquat. Sci. 1. : 19-22.

Gao, X. and J. Song. (2005). Phytoplankton Distributions and Their Relationship with the Environment in The Changjiang Estuary, China. Marine Pollution Bulletin, 50, 327332.

Hadi, B. (2013). Metode Interpolasi Spasial dalam Studi Geografi (Ulasan Singkat dan Contoh Aplikasinya). Geomedia, 11 (2), 231-240.

Hirdan, A., W.R Melany dan T.S. Raza'i. 2016. Hubungan Parameter Kualitas Air dengan Kelimpahan Zooplankton di Perairan Pesisir Desa Sebong Pereh Kecamatan Teluk Sebong Kabupaten Bintan. Jurnal Umrah, Agustus 2016, 1-6.

Makmur, M. Fahrur dan Ruskiah. 2012. Struktur komunitas plankton dan manfaatnya bagi perikanan pesisir Kabupaten Pohuwato di Provinsi Gorontalo. Prosiding Indoaqua Forum Inovasi Teknologi Akuakultur, 857865.

MENLH (Menteri Negara Lingkungan Hidup). (2004). Surat Keputusan Menteri Negara Lingkungan Hidup No.KEP-51/MENLH/ 2004 tentang Baku Mutu Air Laut untuk Biota Laut, Lampiran III.

Morain, S. (1999). GIS Solution in Natural Resource Management: Balancing the echnicalPolitical Equation . USA.: OnWord Press.

Nontji, A. (2008). Plankton Laut. Jakarta: LIPI Press.

Mulyadi, H.A., A. W. Radjab. 2015. Dinamika Spasial Kelimpahan Zooplankton Pada Musim Timur di Perairan Pesisir Morella Maluku Tengah. Jurnal Ilmu dan Teknologi Kelautan Tropis, 7 (1), 109-122.

Ningrum, A.M. dan Wijiyono. 2015. Biological Indication of Zooplankton on Water Ecosystem of Bioremediation Pool PSTABATAN. Seminar Nasional Xi Sdm Teknologi Nuklir Yogyakarta, 15 September 2015, 123128.

Odum, E. 1971. Fundamentals of Ecology. Third edition. Philadelphia, London, Toronto.: W.B. Saunders Company.

Paiki, K. dan J.D Kalor. 2017. Distribusi nitrat dan fosfat terhadap kelimpahan fitoplankton dI Peraiaran Pesisir Yapen Timur. Journal of
Fisheries and Marine Sciencem, 1 (2) : 65-71.

Patmawati, R., H. Endrawati dan A.I Santoso. 2018. The Zooplankton Community Structure in Long Island Waters and Awur Bay, Regency of Jepara. Buletin Oseanografi Marina, 7 (1) : $37-42$.

Pranoto, B. A. 2005. Struktur Komunitas Zooplankton di Muara Sungai Serang, Jogjakarta. Imu Kelautan, 10 (2) : 90 - 97.

Pratono, B.A., Ambariyanto, dan M. Zainuri. 2005. Struktur komunitas zooplankton di muara Sungai Serang, Jakarta. J. Ilmu Kelautan, 10 (2) : 90-97.

Raza'i, T. 2017. Identification and Density of Zooplankton as Natural Food Sources of Fish in The Waters Kampung Gisi, Tembeling, District of Bintan. Intek Akuakultur, 1 (1) : 27-36.

Simanjuntak, M. 2009. The corelation of environment factor chemistry, physics on plankton. . J. Fish. Sci., 11 (1) : 31-45.

Siregar, V.P. and M.B. Selamat. (2009). Interpolator in Bathymetric Map Contouring. E-Jurnal Ilmu dan Teknologi Kelautan Tropis, 1 (1), 39-47.

Spatharis, S., G. Tsirtsis, D.B. Danielidis, T.D. Chi, and D. Mouillot. 2007. Effects of pulsed nutrient inputs on phytoplankton assemblage structure and blooms in an enclosed coastal area. Estuarine, Coastal and Shelf Science, 73 :807-815.

Tambaru, R. A.M. Muhiddin, H.S. Malida. 2014. Analisis Perubahan Kepadatan Zooplankton Berdasarkan Kelimpahan Fitoplankton pada Berbagai Waktu dan Kedalaman Di Perairan Pulau Badi Kabupaten Pangkep. Torani, 24 (3): 40-48.

Wardana, I.K, S.B.M. Sembiring, dan K.Mahardika. 2013. Aplikasi perbaikan manajemen dalam perbenihan tiram mutiara (Pinctada Maxima). Media Akuakultur, 8 (2): 119-126.

Wibowo, A. Wiryanto A.B. Sutomo. 2004. Zooplankton diversity, abundance, and distribution in Digul waters, Arafura Sea, Papua. BioSMART, 6 (1): 51-56.

Widyarini, H., N.T. M. Pratiwi dan Sulistiono. 2017. Zooplankton Community Structure at Majakerta Estuarya and its Surrounding Waters, Indramayu Regency, West Java Province. Jurnal Ilmu dan Teknologi 
Junaidi et al, Jurnal Bologi Tropis, 18 (2) : 159 - 169 DOI: http://dx.doi.org/10.29303/jbt.v18i2.800

Kelautan Tropis, 9 (1): 91-103.

Yamaji, I. (1976). Illustration of the marine plankton of Japan. Tokyo.: Hoikusha Publishing Co. Ltd.

Yuliana dan F. Ahmad. 2017. Komposisi Jenis dan Kelimpahan Zooplankton di Perairan Teluk Buli, Halmahera Timur. Jurnal Ilmiah Agribisnis dan Perikanan, 10 (2) : 44-50. 